\title{
MODEL PEMBELAJARAN JEJARING SOSIAL PADA PELAJARAN MATEMATIKA
}

\author{
Fadli \\ e-mail: fadlibaee@gmail.com \\ STKIP PGRI Lubuklinggau
}

\begin{abstract}
Abstrak: Penelitian ini bertujuan untuk mengembangkan model jejaring sosial pada pelajaran matematika. Responden pada penelitian ini terbatas pada siswa kelas XI IPA MAN 3 Palembang. Penelitian ini dilaksanan pada bulan januari sampai dengan Juni 2013. Metode penelitian yang digunakan yaitu metode Research dan Development (R\&D) dengan menggabungkan model penelitian Borg \& Gall dan model pengembangan Dick \& Carey. Kelayakan dari model yang dikembangkan, peneliti melakukan uji pakar, uji 1-1, uji kelompok kecil, dan uji coba lapangan, dengan melihat minat dan hasil belajar siswa. Hasil penelitian menunjukkan prototype keempat merupakan desain yang potensial efektif ketika digunakan pada saat pembelajaran. Ditunjukkan dengan $65,63 \%$ siswa tertarik terhadap model yang dikembangkan. Selain itu, rata-rata ketuntasan hasil belajar siswa adalah 82,66. Sehingga dapat disimpulkan bahwa model yang peneliti kembangkan valid dan praktis digunakan pada pembelajaran matematika. Implikasinya model yang dikembangkan telah efektif dalam meningkatkan minat belajar siswa pada matematika.
\end{abstract}

Kata kunci: pengembangan, model pembelajaran, jejaring sosial, matematik.

\section{DEVELOPING SOCIAL-HUB INSTRUCTIONAL MODEL IN MATEMATICS}

\begin{abstract}
The purpose of this research was to develop social-hub instructional model in teaching mathematics. Taking place in Government Madrasah Aliyah 3, Palembang as from January through June 2013, the research selected the science students of Grade XI as the respondents. As a research and development project, Borg and Gall model was combined with Dick and Carey model to develop social-hub instructional model. To test the model, this research applied experts, one-to-one, small group, and field tests focusing on the student's interest and learning achievement. The fourth prototype proved the potential design to be effective in the instruction showing $65.63 \%$ of the students interested in the model and the average of mastery learning was 82.66. The findings conclude, the model developed is valid and applicable in teaching mathematics and effective in improving the student's learning motivation in mathematics.
\end{abstract}

Keyword: development, instructional model, social-hub, mathematics.

\section{PENDAHULUAN}

Matematika merupakan ilmu universal yang mendasari perkembangan teknologi modern, mempunyai peran penting dalam berbagai disiplin dan mengembangkan daya pikir manusia. Perkembangan pesat di bidang teknologi informasi dan komunikasi dewasa ini dilandasi oleh perkembangan matematika di bidang teori bilangan, aljabar, analisis, teori peluang dan matematika diskrit. Untuk menguasai dan mencipta teknologi di masa depan diperlukan penguasaan matematika yang kuat sejak dini. (Depdiknas, 2006: 145). Pembelajaran matematika di sekolah bertujuan untuk membantu siswa berpikir memecahkan masalah sehari-hari dengan menggunakan perhitungan matematika. Dalam belajar matematika, siswa harus memperhatikan bagaimana guru menyelesaikan masalah matematika, sehingga dapat mengerti cara menyelesaikannya dan memudahkan dalam menyelesaikan latihanlatihan matematika dan mengaplikasikannya dalam kehidupan sehari-hari. Dengan bantuan media, akan sangat mempermudah siswa memahami materi yang ada.

Perkembangan teknologi informasi dan komunikasi (TIK) beberapa tahun terakhir, sangat berkembang dengan pesat. Hal ini mengubah paradigma masyarakat dalam mencari informasi yang tidak hanya terbatas pada surat kabar, radio, dan televisi, tetapi juga dari sumber dunia maya (virtual). Salah satu dampak yang sangat berarti dalam perkembangan TIK adalah dalam bidang pendidikan. TIK berperan sebagai media komunikasi dan informasi dari guru kepada siswa yang berisikan informasi pendidikan serta sarana penyajian ide dan gagasan dari guru dalam menyampaikan materi pendidikan. 
Menurut Heinich (1996: 8), secara harfiah berarti tengah, perantara atau pengantar, yaitu perantara atau pengantar sumber pesan dengan penerima pesan. Jadi media merupakan sebuah alat yang mempunyai fungsi menyampaikan pesan.

Banyak upaya yang dilakukan oleh pengembang pendidikan dalam rangka meningkatkan prestasi siswa dalam mata pelajaran matematika. Dalam pembelajaran matematika, siswa akan lebih tertarik apabila media yang disampaikan bisa interaktif dengan mereka. Penyajian grafik ataupun contohcontoh soal yang diberi animasi akan membuat minat belajar siswa meningkat. Tugas seorang desainer pembelajaran sangat berperan untuk menyajikan media pembelajaran, khususnya matematika layaknya seperti pemainan games, sehingga siswa akan terus berupaya semaksimal mungkin untuk menyelesaikan games tersebut. Salah satu upaya yang digunakan adalah menggunakan media komputer, dengan membuat pembelajaran matematika interaktif.

Sebagai seorang pengembang pembelajaran, peneliti bermaksud mengembangkan model pembelajaran jejaring sosial pada pelajaran matematika yang dapat mengundang keterlibatan siswa secara aktif dan konstruktif dalam proses belajar terhadap media, sehingga diharapkan terjadinya proses pembelajaran yang menyenangkan, kreatif, dan tidak membosankan.

Menurut pendapat Robins (1996: 25), "A model is an abstraction of reality; a simplified representation of some real-world phenomenon." Maksud dari definisi tersebut, model merupakan representasi dari beberapa fenomena yang ada di dunia nyata. Jadi, model merupakan suatu proses pola pikir dan komponen-komponen yang terdapat di dalamnya yang direpresentasikan dalam bentuk grafis dan/atau naratif.

Dalam mengembangkan model pembelajaran jejaring sosial menurut Miarso (2007: 251), perlu mempertimbangkan kebutuhan pembelajaran, yaitu (a) berpusat pada siswa, (b) belajar dengan berbuat, (c) belajar sepanjang hayat, (d) kolaborasi, (e) pemecahan masalah, (f) kreativitas, dan (g) kemandirian.

Pengembangan pembelajaran paling tidak terdiri dari lima aktivitas utama, yaitu: (a) menganalisis kondisi pembelajaran dan kebutuhan siswa; (b) mendesain rangkaian spesifikasi yang efektif, efisien, dan relevan dengan lingkungan siswa; (c) mengembangkan semua bahan-bahan bagi semua siswa dan manajemen material; (d) implementasi dari hasil rancangan pembelajaran; (e) evaluasi formatif dan sumatif dari hasil pengembangan (Gustafson, 2002: xii-xiii)
Berdasarkan penelitian terdahulu dari Lawanto (2001: 44-58) tentang pembelajaran jejaring sosial sebagai metoda komplemen kegiatan pendidikan dan pelatihan, dan Sutanto (2009: 78-86) yang mengimplimentasikan pembelajaran virtual dengan konsep virtual classroom (VC), maka dikembangkan model pembelajaran jejaring sosial yang memadukan pembelajaran jarak jauh dan tatap muka. Hasil dari kedua penelitian tersebut menunjukkan bahwa pembelajaran melalui web menuntut bukan saja keterampilan siswa mengoperasikan komputer, membaca dan menulis tapi juga menuntut perilaku pribadi yang terbuka, disiplin dan mandiri. Selain itu skenario pembelajaran perlu disiapkan secara matang merancang model pembelajaran jejaring sosial. Mengimplementasikan pembelajaran jejaring sosial bukan berarti sekedar meletakkan materi ajar pada web, tetapi juga mengkombinasikan antara pertemuan secara tatap muka dengan pembelajaran jejaring sosial dapat meningkatkan kontribusi dan interaktifitas antar peserta didik. Artinya melalui tatap muka peserta didik dapat mengenal sesama peserta didik dan guru pendampingnya. Segala persiapan seperti penjadwalan sampai dengan penentuan teknis komunikasi selama proses pembelajaran merupakan tahapan penting dalam melaksanakan pembelajaran jejaring sosial.

Pembelajaran jarak jauh adalah otonomi siswa menentukan proses belajar menggunakan berbagai sumber belajar. Dengan demikian, siswa, guru, maupun sumber belajar dapat terpisah selama atau setidaknya dalam sebagian besar waktu belajarnya (BSNP, 2014: 2). Model pembelajaran jejaring sosial yang dikembangkan setidaknya memiliki unsur-unsur sebagai berikut: (a) pusat kegiatan siswa; (b) adanya materi pembelajaran; (c) adanya interaksi dalam grup; (d) sistem administrasi untuk kebutuhan individu; e) adanya informasi umum; (f) adanya latihan dan evaluasi; (g) adanya materi online di luar materi pokok.

\section{METODE PENELITIAN}

Penelitian dilakukan di MAN 3 Palembang yang telah memiliki sarana dan prasarana memadai untuk mendukung kebutuhan penelitian. Desain dan pengembangan model pembelajaran jejaring sosial pada pelajaran matematika dilaksanakan pada semester ganjil tahun pelajaran 2012/2013. Pelaksanaan uji coba instrumen dilaksanakan pada semester genap tahun pelajaran 2012/2013, sedangkan pengumpulan dan analisis data dilakukan pada semester genap tahun pelajaran 2012/2013. 
Menurut Richey dan Klein (2007: 40), desain dan penelitian pengembangan menggunakan berbagai metodologi. Dalam penelitian ini tidak menggunakan populasi secara umum, tetapi terbatas untuk menggali kedalaman fenomena. Peneliti memilih individu dalam bidang yang diteliti (Creswell, 2005: 213214). Menurut Semiawan (2007: 181), Penelitian dan Pengembangan (R\&D) merupakan perbatasan dari pendekatan kualitatif dan kuantitatif, terutama untuk menjembatani kesenjangan antara penelitian dan praktek pendidikan. Sedangkan menurut Borg dan Gall (2007: 651), R \& D digunakan untuk merancang produk dan prosedur baru, selanjutnya menerapkan metode penelitian untuk ujicoba lapangan, mengevaluasi dan menyempurnakan produk dan prosedur sampai memenuhi kriteria efektif, berkualitas dan berstandarisasi. Penelitian ini bertujuan untuk mengembangkan sesuatu yang baru dan diharapkan dapat meningkatkan mutu hasil belajar matematika siswa. Keterampilan yang akan dikembangkan dalam penelitian ini adalah kemampuan untuk menyelenggarakan model pembelajaranjejaring sosial pada pelajaran matematika. Sedangkan metode penelitian yang digunakan dalam penelitian ini dengan pertimbangan kecocokan dengan sifat penelitian yang akan dilaksanakan yaitu metode Research dan Development (R\&D). Penelitian ini menggabungkan model penelitian Borg \& Gall (1983) dan model pengembangan Dick \& Carey (2005: 1).

Analisis data kualitatif menurut Creswell (2005: 244), ada enam tahapan, yaitu: (1) mengumpulkan data yang akan dianalisis, (2) menyiapkan data yang akan dianalisis, (3) membaca kembali semua data dengan seksama, (4) menganalisis secara mendetil melalui proses pengkodean, (5) mendeskripsikan temuan-temuan dalam kategori atau tema untuk bahan analisis, selanjutnya menyajikan deskripsi dan tema-tema agar memudahkan proses analisis dan penafsiran data, serta (6) menganalisis serta penafsiran data yang dilakukan secara terpadu.

Analisis data kuantitatif berupa kuesioner dalam ujicoba lapangan yang termasuk dalam skala sikap, akan diolah dengan menggunakan skala likert. Sedangkan analisis data kuantitatif berupa tes hasil belajar dituangkan dalam bentuk perhitungan deskriptif.

\section{HASIL DAN PEMBAHASAN}

\section{Hasil Penelitian}

Model pembelajaran yang akan dikembangkan menggunakan pendekatan sistem, sehingga diasumsikan sistem yang mengolah input berupa pemelajar yang belum mempunyai kompetensi menjadi output berupa pemelajar yang mempunyai kompetesi yang diharapkan. Langkah-langkah berdassarkan desain model pembelajaran jejaring sosial pada pelajaran matematika terdiri dari emapat tahap, yaitu: (a) penelitian pendahuluan, (b) tahap mengidentifikasi, (c) tahap mengembangkan, dan (d) tahap mengevaluasi dan merevisi.

Penelitian pendahuluan dilakukan untuk mengidentifikasi perkiraan kebutuhan desain dan pengembangan model pembelajaran jejaring sosial, mempelajari literatur tentang model pembelajaran jejaring sosial, dan persiapan untuk laporan penelitian.

Langkah-langkah yang dilakukan dalam tahap mengidentifikasi adalah melakukan analisis kebutuhan, analisis instruksional dan analisis karakteristik siswa/lingkungan. Analisis kebutuhan dalam pelajaran matematika dilakukan dengan mengidentifikasi tujuan pembuatan model, mengidentifikasi kesenjangan antara keadaan sekarang dengan keadaan yang diharapkan, dilanjutkan sampai kepada proses pelaksanaan pemecahan masalah dan evaluasi terhadap efektifitas dan efisiensinya. Analisis instruksonal berdasarkan BSNP untuk kelas XI IPA semester genap terdapat tiga standar kompetensi (SK) dan sepuluh kompetensi dasar (KD) yang harus dikuasai siswa (Depdiknas, 2006: 156). Analisis karakteristik siswa/lingkungan yaitu menganalisis karakteristik siswa MAN 3 Palembang. Karakteristik siswa yang ada dalam kelas sangat heterogen. Jadwal pelajaran matematika ada yang pagi (setelah bel masuk), setelah istirahat pertama, dan setelah istirahat kedua. Sarana dan prasarana sangat memadai dengan adanya laboratarium komputer yang dilengkapi jaringan internet dan adanya jaringan wifi di ruang kelas. Siswa telah terbiasa menggunakan internet untuk media sosial ataupun mencari tugas sekolah. Siswa MAN 3 Palembang mempunyai tingkat kedisiplinan dan tanggung jawab yang tinggi berdasarkan informasi dari guru.

Langkah-langkah yang dilakukan dalam tahap mengembangkan adalah melakukan perumusan tujuan instruksional khusus (TIK), menyusun tes acuan, mengembangkan strategi instruksional, dan mengembangkan bahan instruksional. Pembelajaran yang akan dikembangkan adalah model pembelajaran jejaring sosial pada pelajaran matematika, berupa model pembelajaran online yang menggunakan web jejaring sosial pembelajaran. Dalam tahap ini, mengaplikasikan rancangan model konseptual ke dalam bentuk model pembelajaran jejaring sosial. Hasil dari pengembangan model pembelajaran jejaring 
sosial pada pelajaran matematika berupa situs web yang beralamatkan di http://www.e-belajarman3. com dan buku panduan penggunaan web buat guru dan siswa.

Langkah-langkah yang dilakukan dalam tahap mengevaluasi dan merevisi dalam penelitian ini merupakan tahapan evaluasi formatif. Tahapan evaluasi formatif yang dilakukan adalah evaluasi ahli, one to one, kelompok kecil, dan ujicoba lapangan.

Tahap awal prototype 1 dilakukan evaluasi ahli untuk mendapatkan informasi tentang kesesuaian materi dengan tujuan pembelajaran, kebenaran konsep, kemutakhiran materi, serta ruang lingkup dan kedalaman materi. Hasil dari revisi prototype 1 menghasilkan prototype 2, sebagai acuan untuk validasi one to one. Setelah dievaluasi, pada umumnya setelah melihat model pembelajaran jejaring sosial, siswa merasa tertarik dan familiar membuka web, dikarenakan mirip seperti facebook. Tingkat keterbacaan siswa terhadap materi limit juga sangat baik, mereka mengerti maksud dari penjelasan materi limit yang dibuat.

Pada prototype 3 dilakukan uji coba kelompok kecil pada siswa kelas XI IPA 4 yang berjumlah 12 orang yang diambil secara acak. Hal ini dilakukan untuk melihat keefektifan model pembelajaran jejaring sosial yang digunakan pada saat pembelajaran. Pembelajaran dilakukan seperti keadaan sesungguhnya, tetapi dengan jumlah siswa lebih sedikit.

Tahap ujicoba lapangan (prototype 4) merupakan tahap praktikalitas yang dilakukan pada siswa kelas XI IPA 2 dan kelas XI IPA 3 MAN 3 Palembang dengan jumlah 64 orang. Evaluasi hasil belajar dilakukan untuk mengetahui tingkat kompetensi siswa setelah menggunakan model pembelajaran jejaring sosial pada pelajaran matematika. Ketuntaasan belajar siswa apabila mendapatkan nilai rata-rata $\geq 80$ berdasaran nilai ketuntasan minimun yang ditetapkan oleh MAN 3 Palembang.

Ketuntasan hasil belajar siswa sebesar 85,94\% dan sisanya sebesar $14,06 \%$ masih belum mencapai ketuntasan. Nilai rata-rata hasil belajar siswa tertinggi dari hasil latihan dan ulangan harian online adalah 100, sedangkan terendah adalah 50. Nilai rata-rata hasil belajar siswa kelas adalah 82,66. Berdasarkan analisis hasil belajar siswa menggunakan model pembelajaran jejaring sosial, menunjukan sangat efektif digunakan. Hal ini berdasarkan nilai rata-rata siswa menunjukkan lebih dari 80. Hasil ini juga diperkuat lebih dari 80\% siswa mencapai kriteria ketuntasan minimum (KKM).

Angket minat siswa diberikan dengan tujuan untuk melihat ketertarikan siswa terhadap mata pelajaran matematika dan model pembelajaran jejaring sosial pada pelajaran matematika. Berdasarkan analisis angket minat siswa terhadap model pembelajaran jejaring sosial, menunjukan 3,13\% siswa sangat tertarik, 65,63\% siswa tertarik, 31,25\% siswa kurang tertarik, dan tidak ada siswa yang tidak tertarik dengan model ini.

Pada gambar 1 berikut merupakan tampilan model pembelajaran jejaring sosial yang telah disosialisaikan di MAN 3 Palembang pada pelajaran matematika.

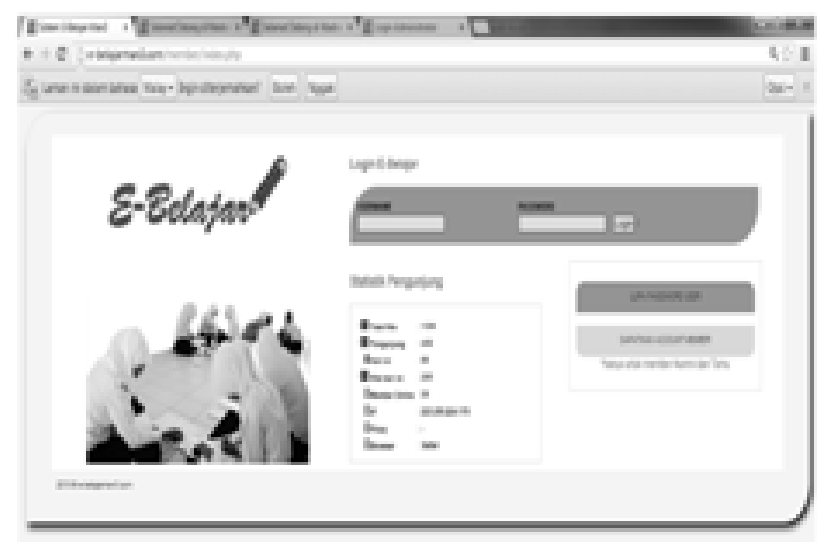

Gambar 1. Tampilan model pembelajaran jejaring sosial (http:/ / www.e-belajarman3.com)

\section{Pembahasan}

Berdasarkan hasil analisis data prototype 1 masih ada kekurangan dalam web yang dibuat, perbaikan dilakukan berdasarkan saran dari ahli materi, ahli media web, dan ahli desain instruksional. Pada prototype 1 pengembangan model pembelajaran jejaring sosial pada pelajaran matematika sebagai tahap ujicoba. Revisi prototype 1 sebagai dasar untuk evaluasi one to one $(1-1)$. Hasil dari revisi prototype 2 menghasilkan prototype 2 . Berdasarkan hasil analisis data prototype 2, pada umumnya setelah melihat model pembelajaran jejaring sosial, siswa merasa tertarik dan familiar membuka web, dikarenakan mirip seperti facebook. Siswa mengerti kegunaan dari tombol-tombol navigasi dari model tersebut. Tingkat keterbacaan siswa terhadap materi limit juga sangat baik, mereka mengerti maksud dari penjelasan materi limit yang dibuat. Hasil tahap prototype 2 ini menghasilkan prototype 3, yang digunakan untuk uji coba kelompok kecil. Hasil selama kegiatan pembelajaran diperoleh tingkat motivasi siswa belajar secara mandiri dengan menggunakan model pembelajaran jejaring sosial rata-rata mempunyai tingkat motiviasi dengan kategori termotivasi dan minat siswa terhadap model pembelajaran jejaring sosial rata-rata mempunyai minat dengan kriteria 
tertarik. Hasil dari revisi prototype 3 menghasilkan prototype 4, yang digunakan untuk ujicoba lapangan.

Hasil pada prototype 4, menunjukkan bahwa prototype 4 lebih baik dari prototype 3. Berdasarkan analisis hasil belajar siswa menggunakan model pembelajaran jejaring sosial pada pelajaran matematika, menunjukan sangat efektif digunakan. Hal ini berdasarkan nilai rata-rata siswa perkelas ataupun gabungan menunjukkan hasil rata-rata lebih dari 80 (nilai ketuntasan minimum). Sedangkan berdasarkan analisis angket minat siswa terhadap model pembelajaran jejaring sosial, menunjukan 3,13\% siswa sangat tertarik, 65,63\% siswa tertarik, 31,25\% siswa kurang tertarik, dan tidak ada siswa yang tidak tertarik dengan model ini. Ini menunjukkan prototype 4 telah potensial efektif dan efisien dalam memperbaiki minat siswa dan meningkatkan hasil belajar. Oleh karena itu, prototype 4 dianggap sebagai hasil akhir dari pengembangan model pembelajaran jejaring sosial pada pelajaran matematika.

Hasil akhir dari pengembangan model pembelajaran jejaring sosial pada pelajaran matematika menghasilkan beberapa karakteristik model yang dikembangkan. Karakteristik model pembelajaran jejaring sosial pada pelajaran matematika, yaitu: (1) telah tercapainya kompetensi dasar dengan telah tercapainya ketuntasan sebesar 85,94\%; (2) telah sesuai dengan karakteristik siswa kelas XI IPA MAN 3 Palembang yang memiliki litetasi TIK yang baik dengan tidak terdapatnya keluhan dalam menggunakan model pembelajaran jejaring sosial; (3) telah terjadinya interaksi antara siswa dengan komputer, siswa dengan siswa, siswa dengan guru, dengan memanfaatkan fasilitas chatting dan grup; (4) telah meningkatnya kesukaan siswa terhadap pembelajaran matematatika dari $43,75 \%$ menjadi lebih dari $70 \%$ menyukai pembelajaran matematika setelah menggunakan model pembelajaran jejaring sosial ini; (5) telah terciptanya suasana belajar mandiri ditunjukan dengan rata-rata hasil belajar siswa sebesarr 82,66; (6) telah efektif dalam memberikan umpan balik dengan munculnya skor setelah menyelesaikan latihan maupun evaluasi secara interaktif; (7) telah adanya menu untuk membuat simbol matematika pada tes online; (8) telah adanya materi video pembelajaran yang bersumber dari youtube; (9) telah dirancang berdasarkan prinsip desain pembelajaran dengan dimulainya tutorial materi dan diakhiri dengan pemberian latihan akhir pembajaran; dan (10) telah dievaluasi melalui evaluasi ahli yang terdiri dari ahli materi, ahli media web dan ahli desain instruksional. Selanjutnya dilakukan evaluasi one to one, evaluasi kelompok kecil dan ujicoba lapangan terhadap siswa kelas XI IPA 2 dan kelas XI IPA 3 MAN 3 Palembang.

Didasarkan kepada penelitian relevan yang dilakukan oleh para ahli dibidangnya, memperlihatkan bahwa pengembangan model pembelajaran jejaring sosial pada pelajaran matematika telah menghasilkan karakteristik hasil penelitian yang memanfaatkan web sebagai media pembelajaran. Model pembelajaran jejaring sosial pada pelajaran matematika menunjukan bahwa produk pengembangan dapat memberikan dampak kepada peningkatan dan perbaikan cara belajar dengan memanfaatkan web pembelajaran. Model pembelajaran jejaring sosial pada pelajaran matematika, didesain seperti layanan jejaring sosial facebook. Facebook merupakan layanan jejaring sosial yang memanfaatkan situs web, agar semua orang bisa membuat profil pribadi yang bertujuan mencari teman atau keluarga yang tidak pernah dijumpai atau bertemu.

Model pembelajaran jejaring sosial yang dikembangkan menyarankan agar penerapan prinsip desain pembelajaran disesuaikan dengan langkahlangkah yang harus di tempuh secara berurutan, dengan kata lain harus prosedural. Sesuai dengan model pengembangan dari Dick \& Carey, model yang dikembangkan memandang setiap komponen bersifat penting dan tidak boleh ada yang dilewati. Dalam Model Dick \& Carey, tahap pengembangan tidak secara detail menjelaskan langkah-langkah dalam proses pembelajaran jejaring sosial. Oleh karena itu, model pembelajaran jejaring sosial pada pelajaran matematika telah mengakomodir hal tersebut. Model yang dikembangkan merupakan perwujudan dari teori dan prinsip dari model 3P (Pengguna, Proses, Produk) diintegrasikan dengan kerangka teori pembelajaran yang diadaptasi dari Reigeluth, menggunakan langkah-langkah prosedural dari Dick \& Carey, yang terdiri dari tiga tahap, yaitu : a) tahap mengidentifikasi; b) tahap mengembangkan; dan c) tahap mengevaluasi dan merevisi. Sebelum tiga tahapan dalam model prosedural dilaksanakan, terlebih dahulu dilakukan penelitian pendahuluan dari Borg \& Gall. Dalam proses pengembangan fasefase dalam model ini jelas dan teratur, sehingga proses pengembangan akan efektif dan efisien.

Beberapa catatan penting yang ditemukan selama pelaksanaan penelitian adalah model pembelajaran jejaring sosial pada pelajaran matematika harus dipersiapkan terlebih dahulu sebelum digunakan dalam pembelajaran. Persiapan yang dilakukan dari mulai memasukan materi, alat evaluasi, proses pembelajaran, sampai waktu dalam 
pemanfaatan model tersebut. Artinya model tidak bisa digunakan oleh siswa secara langsung begitu saja untuk pembelajaran online, tetapi harus direncanakan terlebih dahulu. Dalam hal ini, model hanya bisa digunakan sebagai pelengkap atau pengkayaan dalam pembelajaran saja, yaitu dengan memanfaatkan materi dan jejaring sosial yang ada. Konsekuensinya dari temuan ini adalah sebelum model digunakan oleh siswa, maka terlebih dahulu perlu dilatih guru mata pelajaran dalam proses pendesainan pembelajaran.

Hasil penelitian ini juga memiliki beberapa hambatan sehingga diharapkan pengembangan model pembelajaran jejaring sosial selanjutnya dapat menggunakannya sebagai acuan. Beberapa hambatan dalam proses pengembangan model pembelajaran berbasis web pada pelajaran matematika, yaitu: (1) dari model prosedural, langkah pengembangan hanya sampai evaluasi formatif, tidak sampai pada evaluasi sumatif. Hambatan yang dihadapi adalah masalah dana yang besar dan waktu yang lama dalam implimentasi dan diseminasi; (2) diperlukan biaya yang tinggi untuk dapat memproduksi model pembelajaran berbasis web pada pelajaran matematika, karena untuk menghasilkan web yang baik dan dapat dipertanggungjawabkan memerlukan seorang programmer yang handal untuk dapat mengaplikasikan model konseptual yang telah dibuat; (3) sumber belajar seperti model pembelajaran berbasis web pada pelajaran matematika membutuhkan keahlian khusus dalam merancang pembelajaran; (4) diperlukan waktu yang lama dalam mengembangkan model pembelajaran berbasis web pada pelajaran matematika, mulai dari penelitian pendahuluan, tahap mengidentifikasi, tahap mengembakan, serta tahap mengevaluasi dan merevisi; dan (5) karena model pembelajaran berbasis web pada pelajaran matematika bersifat online, maka model ini sangat bergantung dengan sistem jaringan atau koneksitas.

\section{PENUTUP}

\section{Kesimpulan}

Proses desain dan pengembangan model pembelajaran jejaring sosial pada pelajaran matematika menggunakan penelitian dan pengembangan (R\&D). Model pembelajaran jejaring sosial pada pelajaran matematika yang dapat diakses pada alamat http:/ / www.e-belajarman3.com. Model pembelajaran jejaring sosial pada pelajaran matematika dapat meningkatkan penguasaan kompetensi pelajaran matematika siswa kelas XI IPA MAN 3 Palembang. Ini menunjukan bahwa model yang dikembangkan telah potensial efektif dalam memperbaiki minat siswa dan meningkatkan hasil belajar siswa.

Implikasi dari penelitian ini, model yang dikembangkan efektif dalam meningkatkan minat belajar siswa pada pelajaran matematika. Ditunjukan, sebelum menggunakan model pembelajaran jejaring sosial pada pelajaran matematika, moyoritas siswa kurang tertarik dengan pembelajaran pada pelajaran matematika, tetapi setelah menggunakan model pembelajaran jejaring sosial pada pelajaran matematika, mayoritas siswa tertarik dengan pelajaran matematika. Hal ini dikarenakan model yang dikembangkan mempunyai ciri khas seperti jejaring sosial yang menyerupai facebook. Artinya, siswa lebih tertarik belajar matematika setelah diberikan model pembelajaran jejaring sosial ini.

Model pembelajaran jejaring sosial pada pelajaran matematika terbukti sebagai model yang efektif dan menarik maka disarankan kerjasama tim guru mata pelajaran dengan pembagian tugas yang jelas antar guru, dan atau kerja sama dengan institusi lain yang relevan. Misalnya penyiapan materi pembelajaran online, menyediakan latihan dan tugastugas yang mendorong siswa belajar aktif, interaktif, dan kolaboratif. Untuk lebih memantapkan model pembelajaran jejaring sosial ini, disarankan agar model pembelajaran ini digunakan untuk kelas dan mata pelajaran lain.

\section{DAFTAR PUSTAKA}

Badan Standar Pendidikan Nasional. (2014). Drat standar pendidikan jarak jauh. Jakarta.

Creswell, J.W. (2005). Educational research. Upper Sadle River, NJ: Pearson.

Depdiknas. (2006). Standar isi untuk satuan pendidikan dasar dan menengah. Jakarta: Badan Standar Nasional Pendidikan.

Dick, W., Carey, L. \& Carey, J.O. (2005). The systematic design of instruction. Boston: Pearson. 2005.

Gall, M., Gall, J.P., Borg, W.R. (2007). Educational research. USA: Pearson Educatio, Inc.

Gustafson, K.L. \& Branch, R.M. (2002). Survey of instructional development models. New York: Eric Clearinghause in Information \& Technology Syracuse University.

Heinich, R., et.al. (1996). Instructional media and technologies for learning. New Jersey: Upper Saddle River.

Lawanto, O. (2011). Pembelajaran jejaring sosial sebagai metode komplemen kegiatan pendidikan dan pelatihan. (http://repository.ubaya.ac.id /51/1/ ART004.pdf, diakses 28 Oktober 2011).

Miarso, Y. (2007). Menyemai benih Teknologi Pendidikan. Jakarta: Kencana Prenada Group.

Perspektif Ilmu Pendidikan - Vol. 28 No. 2 Oktober 2014 
Pusat Kurikulum Badan Penelitian dan Pengembangan. (2010). Panduan pengembangan pendekatan belajar aktif. Jakarta: Kementerian Pendidikan Nasional.

Pusat Penelitian Kebijakan dan Inovasi Pendidikan Badan Penelitian dan Pengembangan. (2008). Metode penelitian pengembangan. Jakarta: Departemen Pendidikan Nasional.

Richey, R.C. \& Klein, J.D. (2007). Design development and research. New Jersey: Lawrence Erlbaum Associates.

Robins, S.P. (1996). Organizational behavior: Concepts, controversies, applications. New York: Prentice Hall, Inc.
Semiawan, C.R. (2007). Catatan kecil tentang penelitian dan pengembangan ilmu pengetahuan. Jakarta: Kencana Prenada Media Grup.

Sutanto, B. (2009). Jejaring sosial classroom: Strategi pembelajaran berbasis synchronous e-learning. Seminar Nasional Aplikasi Teknologi Informasi. (http://journal.uii.ac.id/index.php/ Snati/article/ view File/1221/1009, diakses 30 Oktober 2011)

Tambunan, H. Pengembangan pembelajaran jejaring sosial site dalam mata kuliah Pengaturan Mesin Listrik (http://journal.uny.ac.id/index.php/ cp/article/download/1260/pdf, diakses 30 Oktober 2013) 